ELORE (ISSN 1456-3010), vol. 17 - 2/2010.

Julkaisija: Suomen Kansantietouden Tutkijain Seura ry.

[http://www.elore.fi/arkisto/2_10/ukkonen_2_10.pdf]

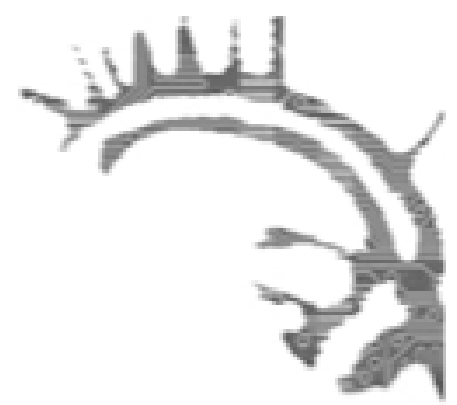

KiRJA-ARVIO

\title{
SUOMALAISEN MUISTITIETOTUTKIMUKSEN YDINKYSYMYKSIÄ
}

MAKKONEN, ELINA 2009: Muistitiedon etnografiaa tuottamassa. Joensuun yliopiston humanistisia julkaisuja 58. Joensuu: Joensuun yliopisto.

\section{Taina Ukkonen}

Elina Makkosen perinteentutkimuksen väitöskirja Muistitiedon etnografiaa tuottamassa koostuu kuudesta, vuosina 2005-2008 julkaistusta artikkelista ja niihin liittyvästä johdannosta. Siinä tarkastellaan kolmea Pohjois-Karjalaan paikantuvaa muistitietohanketta, joissa kaikissa Makkonen on itse ollut mukana. Näissä hankkeissa on tuotettu paikallisten ryhmien ja yhteisöjen omaa historiaa, mutta samalla niihin on liittynyt akateemisen tutkimuksen intressejä. Tutkimuksen pääkysymys on, miten menneisyyttä tuotetaan muistelutilanteissa, erilaisissa muisteluaineistoissa ja muistitietohankkeissa.

\section{Mitä ON MUISTITIETOETNOGRAFIA?}

Makkosen tarkastelemissa hankkeissa tuotettiin monenlaista muistitietoa ja monella eri tavalla: niiden yhteydessä toimi muistelu- tai perinnepiirejä, kirjoitettiin kylälehtiä ja -kirjoja, piirrettiin muistipiirroksia ja tehtiin haastatteluja, joista osa on ryhmähaastatteluja. Makkonen analysoi haastatteluja muistitiedon tuottamisen kontekstina ja tekee näkyväksi niitä menneisyyden tulkintoja, joita on luettavissa haastatteluista ja muistipiirroksista. Lisäksi hän pohtii, miten yhteisöjen (Kaltimo, Kontiolahden kylät) tai instituution (Joensuun yliopisto) historiaa rakennetaan sekä tarkastelee, minkälaisia menneisyyttä koskevia neuvotteluja käydään ja ketkä tulkinnoista neuvottelevat eli ketkä tuottavat ja muokkaavat menneisyys- ja historiakuvia. 
Taina Ukkonen: Suomalaisen muistitietotutkimuksen ydinkysymyksiä

Tarkastelun perustana on ymmärtävä muistitietotutkimus, jota Makkonen "vahvistaa etnografisella näkökulmalla”. Etnografisuus tarkoittaa käytännössä sitä, että tutkija kertoo, miten haastatteluaineistot on muodostettu ja analysoitu sekä minkälaisia eettisiä kysymyksiä aineiston muodostamisen ja tutkimuksen kirjoittamiseen liittyy. Keskeistä on tehdä näkyväksi tutkijan oma rooli ja sen näkyminen tutkimuksen kaikissa vaiheissa. Makkosen omin sanoin "muistitietoetnografian tutkimusote korostaa tutkijan roolia ja merkitystä yhtenä tutkimustiedon tuottajana ja vaatii tutkijaa kirjoittamaan auki omat tavoitteensa, sitoumuksensa ja vaikutuksensa tuotettuun tietoon" (s. 61). Olennaista muistitietoetnografiassa on muistitiedon ja etnografisen tiedon dialogi ja neuvottelu.

Tutkimusote on hyvä, mutta vierastan sen kutsumista muistitietoetnografiaksi, koska tavoitteena ei ole kirjoittaa kattavaa kuvausta muistitiedosta vaan sen tuottamisprosessista. Tutkimuksen kohteena olevien yhteisöjen tuntemus, haastattelujen tekeminen, aineistojen analysointi laadullisin menetelmin sekä refleksiivinen ote tutkimuskohteen kuvailussa ja tutkimuksen kirjoittamisessa kuuluu lisäksi hyvin olennaisesti nimenomaan haastatteluihin perustuvaan muistitietotutkimukseen. Toisaalta muistitietotutkimuksessa hyödynnetään myös muulla tavoin kuin haastattelemalla hankittua aineistoa, joten ehkä etnografiseen metodologiaan tukeutumista olisi hyvä korostaa omalla nimityksellä. Eikö etnografinen muistitietotutkimus olisi kuvaava ja sopiva?

\section{Muistitieto Tietona JA TUtKimusaineistona}

Viime vuosien aikana folkloristiikassa on ilmestynyt useita muistitietotutkimuksen kenttään kuuluvia väitöskirjoja (esim. Haanpää 2008, Kortelainen 2008 ja Heimo 2010). Niissä kaikissa käsitellään haastatteluja tutkimusaineiston ja tiedon muodostamisen tapana, muistitiedon ominaispiirteitä tietona ja menneisyyden tulkintana sekä tutkimuksen tekemiseen liittyviä eettisiä kysymyksiä ja valintoja. Lisäksi tutkimuksissa esitellään joitakin muistelijoita sekä maallikkotutkijoita, paikallisen historian asiantuntijoita tai "muistin miehiä" ja pohditaan näiden tuottaman historiallisen tiedon merkitystä ja suhdetta asiantuntijahistoriaan. Myös Makkonen paneutuu väitöskirjassaan näihin suomalaisen muistitietotutkimuksen ydinkysymyksiin.

Muistitiedon ominaispiirteiden tarkastelu on siis nykyisin olennainen osa muistitietotutkimusta. Kunkin tutkimuksen tieteenfilosofisista lähtökohdista ja tavoitteista riippuu, minkälaisiin piirteisiin tarkastelussa keskitytään; keskitytäänkö pohtimaan muistitiedon sisällöllisiä piirteitä, tehtäviä, ilmaisukeinoja vai esimerkiksi suullisen muistitiedon suhdetta kirjallisessa muodossa oleviin aineistoihin. Näissä muistitiedon luonnetta käsittelevissä pohdinnoissa korostetaan useimmiten seuraavia asioita: muistitiedossa menneisyyttä kuvataan ja arvioidaan nykyisyys lähtökohtana, toiseksi muistitiedossa kietoutuvat yhteen muistelijan omat kokemukset ja erilaiset julkiset diskurssit tai tekstit ja kolmanneksi se on moniäänistä tulkintaa, joka kertoo ensisijaisesti menneiden asioiden ja tapahtumien merkityksestä ei niinkään siitä, miten 
asiat olivat (esim. Haanpää, 2008, 37-40; Kortelainen 2008, 27-33).

Tutkimuksensa johdannossa Makkonen luonnehtii muistitietoa samalla tavoin kuin kollegansa, yhtäl̈ltä yksilöllisenä, toisaalta yhteisöllisenä, moniäänisenä ja tulkinnallisena tietona, jota voi käyttää sekä kohteena että lähteenä. Itse hän tarkastelee muistitietoa molempina ja määrittää työnsä samalla aineistoa tuottavaksi muistitietotutkimukseksi. Artikkelissa Lapsuus menneen ja nykyisen vuoropuhelussa: kaltimolaisten muistelupuheen tarkastelua Makkonen syventää pohdintojaan muistitiedon luonteesta. Hän osoittaa, millä tavoin nykyisyys on muistelussa läsnä ja esittelee keskeiset aiheet, joiden kautta lapsuutta muistellaan. Samat aiheet - kova työnteko pienestä pitäen, leikki ja kasvatusmenetelmät - toistuvat sivumennen sanoen myös siinä lapsuutta käsittelevässä muistitietoaineistossa, jonka parissa itse parhaillaan työskentelen.

Artikkelissa Instituution suullinen historia Makkonen tarkastelee, miten Joensuun yliopiston historiaan liittyviä asioita käsitellään haastatteluissa. Tässä yhteydessä tulee hyvin esille, millä tavoin yksityinen historia ja yleinen historia limittyvät muistitiedossa. Artikkelissa tulee esille myös se, että instituution historiaan liittyvä muistitieto on usein kovin yleisluontoista ja suoraan sanoen aika mitäänsanomatonta. Instituution vaiheet eivät ilmeisesti innosta muistelijoita eivätkä ole samalla tavoin muistamisen arvoisia tai selitystä kaipaavia kuin vaikkapa vuoden 1918 tapahtumat (Heimo 2010) tai suvussa tapahtunut veljestappo (Haanpää 2008).

\section{HAASTATTELU TUTKIMUSAINEISTON MUODOSTAMISEN TAPANA}

Haastattelu on muistitietotutkimuksessa olennainen aineiston muodostamisen tapa myös silloin, kun on hyödynnetty muulla tavoin tuotettua muistitietoa. Makkonen on tehnyt haastatteluja kaikissa muistitietohankkeissaan, menetelmänään teemahaastattelu. Käyttämäänsä teemalistaan hän tukeutui alussa "aika orjallisesti", myöhemmin "keskustelevammin" ja viimeisessä, Joensuun yliopiston muistitietoprojektissa "luovasti" (s. 43-44). Teemahaastattelua tai sen ja avoimen haastattelun yhdistelmää ovat käyttäneet muutkin muistitietotutkijat, ja kaikki ovat myös yhtä mieltä siitä, että haastattelussa aineisto ja tieto tuotetaan vuorovaikutuksessa tai dialogissa.

Minua ihmetyttää se, että teemahaastattelusta on tullut niin itsestään selvä aineiston muodostamisen tapa suomalaisessa muistitietotutkimuksessa. Miksi tutkijat eivät pyri kehittämään nimenomaan muistitietotutkimukseen soveltuvia haastattelumenetelmiä? Jos haastattelun on suositeltavaa olla dialogia tai ainakin "keskusteleva", niin tämä vaatii sen pohtimista, millä keinoin kunnon vuoropuhelua saadaan aikaan. On mietittävä, millä tavoin kysytään ja otetaan uusia aiheita esille, millä tavoin kommentoidaan haastateltavan puhetta ja tehdään siitä tulkintoja.

Makkonen kirjoittaa johdannossa haastatteluista aika yleisluontoisesti ja niin, että painopiste on niissä muutoksissa, joita etnografiassa ja muistitietotutkimuksessa on tapahtunut suhteessa haastatteluihin. Lisäksi hän kirjoittaa, että "haastattelussa tapahtuvan kohtaamisen lähtökohtana ovat lähes poikkeuksetta tutkijan toiveet ja 
odotukset" eli tutkija ohjaa ja johtaa silloinkin, kun haastateltava saa kertoa vapaasti. Tästä olen eri mieltä, sillä kokemukseni mukaan myös haastateltavilla on omat odotuksensa ja keinonsa hallita tilannetta. Näitä keinoja ovat esimerkiksi tutkijan esittämien aiheiden ohittaminen, vaikeneminen ja tutkijan tulkintojen, toisinaan jopa tutkijan pätevyyden kiistäminen. Eettisistä kysymyksistä kirjoittaessaan Makkonen itsekin myöntää, että aina ei ole selvää, kuka haastatteluissa käyttää eniten valtaa. Sen sijaan aineiston analyysissa ja tulkinnassa tutkijan valta on todellakin suuri, vaikka hän pyrkisikin keskustelemaan tulkinnoistaan muistelijoiden kanssa.

Artikkelissa Producing the Past together: Group Interview and Oral History Makkonen syventyy ryhmähaastatteluihin. Hän kuvaa hankkeidensa erilaisia ryhmähaastatteluja ja sitä, millä tavoin niissä muisteltiin ja käytiin neuvotteluja menneisyyden tulkinnoista. Hän myös osoittaa, että sisarusryhmässä ja avioparin muodostamassa ryhmässä (pitäisiköhän muuten puhua myös parihaastattelusta?) muistelijoiden väliset asetelmat ja vuorovaikutustavat ovat melko lailla samat kuin arkitilanteissa, kun taas nimenomaan haastattelua varten kokoontuneissa ryhmissä valta-asetelmat ja muistelemisen tavat muodostuvat vasta haastattelun kuluessa. Makkonen pitää ryhmähaastatteluja hyvänä aineiston muodostamisen menetelmänä, koska ryhmässä muistelijat voivat virkistää toistensa muistia ja pohtia asioita yhdessä.

\section{KENTTÄ OPETTAA}

Elina Makkosen väitöskirjan johdanto on melko yleisluontoinen ja esittelee pääasiassa suomalaista muistitietotutkimusta, mutta se toimii hyvänä johdatuksena sekä artikkeleihin että niihin aiheisiin, jotka muistitietotutkimuksessa ovat olleet keskeisiä. Poikkeuksen tästä yleisluontoisuudesta tekee alaluku Eettisiä pohdintoja, jossa Makkonen käsittelee koko tutkimusprosessiin, ei pelkästään haastattelutilanteisiin ja muistelijoiden henkilöllisyyden suojaamiseen, liittyviä eettisiä kysymyksiä ja valintoja.

Väitöskirjan artikkelit kuvaavat monipuolisesti sitä, miten muistitietohanke toteutetaan, miten hankkeissa ja erilaisissa haastatteluissa muistellaan ja käydään neuvotteluja. Elina Makkonen onkin "kentällä" eli muistitietohankkeissa pätevöitynyt tutkija. Kokemukseni mukaan muistitietotutkimusta oppii tehokkaimmin käytännössä, toteuttamalla hankkeita ja tekemällä yhteistyötä muistelijoiden kanssa. Myös muistin toiminnasta, muistitiedon ominaispiirteistä ja tuottamistavoista saa hankkeissa ja muistelijoiden parissa enemmän ja syvällisempää tietoa kuin tutkimuskirjallisuutta lukemalla. Etnografinen tutkimusote sopii siis muistitietotutkimukseen erittäin hyvin. 


\section{KIRJALlisuUs}

HAANPÄÄ, RIINA 2008: Rikosten jäljet. Etsivän työtä yhteisön, suvun ja perheen muistissa. Scripta Lingua Fennica Edita 270. Turku: Turun yliopisto.

HEIMO, ANNE 2010: Kapina Sammatissa. Vuoden 1918 paikalliset tulkinnat osana historian yhteiskunnallisen rakentamisen prosessia. Suomalaisen Kirjallisuuden Seuran toimituksia 1275 . Helsinki: SKS.

KORTELAINEN, KAISU 2008: Penttilän sahayhteisö ja työläisyys. Muistitietotutkimus. Suomalaisen Kirjallisuuden Seuran toimituksia 1178. Helsinki: SKS.

Filosofian tohtori Taina Ukkonen tekee muistitietotutkimusta Tilkasten-Värrin sukuseuran Suvun tarinat talteen -hankkeessa. 